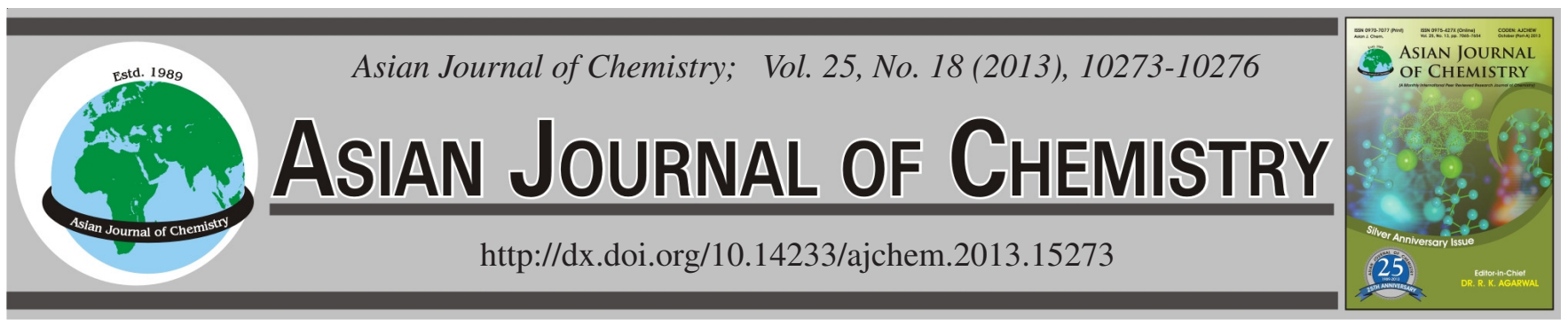

\title{
Using Co-Solvent Approach to Improve the Performance of Lipase from Thermomyces lanuginosus in Preparation of 5'-O-Palmitoyl-6-azauridine
}

\author{
YANHONG Bi ${ }^{1}$, ZhaOyu Wang ${ }^{1,2, *}$, Linghong NiE ${ }^{1}$ and XIANGQIAN Li ${ }^{1,2}$
}

\begin{abstract}
${ }^{1}$ School of Life Science and Chemical Engineering, Huaiyin Institute of Technology, Huai'an 223003, P.R. China
${ }^{2}$ Jiangsu Provincial Engineering Laboratory for Biomass Conversion and Process Integration, Huai'an 223005, P.R. China
\end{abstract}

*Corresponding author: Tel/Fax: +86 517 83591165; E-mail: biowzy@ 126.com

(Received: 4 February 2013;

Accepted: 14 November 2013)

AJC-14383

\begin{abstract}
Organic co-solvents can improve the catalytic power, activity and stability of the enzyme. In this paper, regioselective transesterification of 6-azauridine with vinyl palmitate using immobilized lipase from Thermomyces lanuginosus in the co-solvent system was described. The optimum conditions were screened out. The optimal volumetric ratio of the co-solvent mixture, molar ratio of 6-azauridine to vinyl palmitate and reaction temperature were found to be acetone/isooctane $(90: 10 \mathrm{v} / \mathrm{v}), 1: 5$ and $50{ }^{\circ} \mathrm{C}$, under which the reaction rate, substrate conversion and 5'-regioselectivity were $20.6 \mathrm{mM} / \mathrm{h},>99.0$ and $99.0 \%$, respectively. Moreover, the thermal stability and operational stability of the enzyme were enhanced expressly by changing the reaction solvent from pure acetone to a mixture of acetone and isooctane.
\end{abstract}

Key Words: Acylation, 6-Azauridine, Co-solvent, Thermomyces lanuginosus lipase.

\section{INTRODUCTION}

Results obtained from the synthetic application of biocatalysts indicate that the organic solvent profoundly influenced enzyme performance ${ }^{1,2}$. However, in many cases, the troublesome limitations of the inactivation of enzymes and poor substrate solubility in organic solvents prevent further application of enzymes in fine chemistry. For instance, one of the most impracticable limitations in the acylation of hydrophilic polyhydroxy compounds is their limited solubility in hydrophobic solvent, which is advantageous to the stabilization of enzyme ${ }^{3}$. Therefore, in order to overcome these drawbacks, many strategies to improve lipase activity and stability have been explored from a practical and economic point of view ${ }^{1}$.

Recently, regioselective enzymatic acylation of nucleosides has emerged as a promising procedure which has been profitably applied for preparing new drugs with improved pharmacokinetic and therapeutic properties ${ }^{4,5}$. 6-Azauridine (AzUrd), as a kind of the natural pyrimidine nucleoside analogs, has been acting as the current effective antitumor or antiviral agents for many years ${ }^{6,7}$. Whereas, it has been well described that the fatty acid esters of 6-azauridine have higher activity, stability and pharmacokinetic profile compared with the parent $\mathrm{drug}^{8}$. Nevertheless, conventional chemical methods for selective acylation of nucleosides suffer from the low regioselectivity, tedious product isolation and environmental concerns of the process ${ }^{9}$. In this sense, many ester derivatives of 6-azauridine via an enzymatic acylation route have been synthesized in our previous reports ${ }^{10-12}$. Unfortunately, the results indicated that the enzyme in pure organic solvents would lead to poorer thermal and operational stability, presumably due to the destruction of the hydration layer of the enzyme in hydrophilic solvent or the lower substrate solubility in hydrophobic medium ${ }^{13,14}$.

It is reported that the use of co-solvent mixture can effectively improve the reusability stability in comparison with pure organic solvents in the process of enzymatic reaction ${ }^{2}$. More recently, the regioselective approach in co-solvents by Novozym 435 lipase has proved to be a successful strategy for efficient acylation of nucleosides, such as 1- $\beta$-D-arabinofuranosylcytosine and 5-fluorouridine ${ }^{15,16}$. Herein, we continued to extend our interest to choose the palmitoylation of 6-azauridine as a model reaction with the aim of investigate the behaviour of the Thermomyces lanuginosus lipase in a binary mixture of organic solvents (Scheme-I).

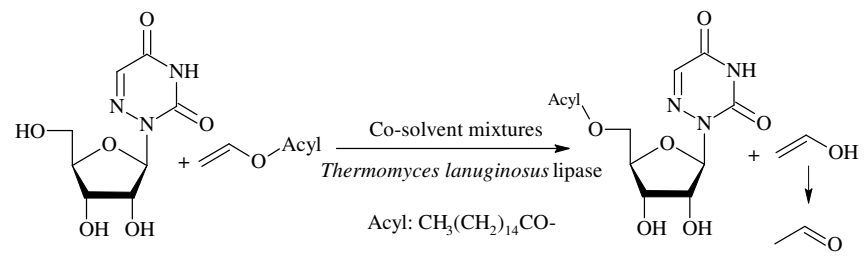

Scheme-I: Thermomyces lanuginosus lipase-catalyzed regioselective acylation of 6-azauridine with vinyl palmitate 


\section{EXPERIMENTAL}

TLL (lipase from Thermomyces lanuginosus, immobilized on granulated silica; specific activity, 50,000 U/g) was purchased from Novozymes, Denmark. Vinyl palmitate was purchased from TCI. 6-Azauridine was obtained from Aldrich. All other chemicals were also from commercial sources and of the highest purity available.

General procedure for enzymatic reaction: In a typical experiment, $2 \mathrm{~mL}$ organic solvent containing $0.02 \mathrm{mmol} 6-$ azauridine, $750 \mathrm{U}$ TLL and $0.1 \mathrm{mmol}$ vinyl palmitate was incubated in a $10 \mathrm{~mL}$ Erlenmeyer shaking-flask capped with a septum under predetermined reaction conditions. Aliquots were withdrawn at specified time intervals from the reaction mixture and then diluted 50 times with corresponding mobile phase prior to HPLC analysis.

Determination of residual enzyme activity: The enzyme was recovered after reaction for $6.5 \mathrm{~h}$ and its residual activity was determined. After decanting the solvent, the immobilized enzyme was dried under vacuum for $2 \mathrm{~h}$. The residual activity was determined in a reaction system composed of $0.02 \mathrm{mmol}$ of 6-azauridine, $0.1 \mathrm{mmol}$ of vinyl palmitate and $2 \mathrm{~mL}$ of co-solvent mixture of anhydrous acetone/isooctane at $200 \mathrm{rpm}$ and $50{ }^{\circ} \mathrm{C}$. The initial rate of acylation was used as a measure of enzyme activity. The relative activity was expressed as the ratio of the enzyme activity of the recovered enzyme preparation to that of the fresh enzyme preparation in the same reaction system.

Determination of enzyme thermal stability: In order to assess the thermal stability of enzyme, $750 \mathrm{U}$ of TLL was added into separate screw-capped vials containing $2 \mathrm{~mL}$ of the appropriate anhydrous medium and incubated for $6.5 \mathrm{~h}$ at various temperatures from $35-55^{\circ} \mathrm{C}$. Then the immobilized enzyme was recovered and added into the above mentioned fresh reaction medium containing $0.02 \mathrm{mmol}$ of 6 -azauridine, $0.1 \mathrm{mmol}$ of vinyl palmitate at $200 \mathrm{rpm}$ and $50{ }^{\circ} \mathrm{C}$, followed by the assay of its activity for catalyzing the reaction.

HPLC analysis: The reaction mixture was analyzed by RP-HPLC on a $4.6 \mathrm{~mm} \times 250 \mathrm{~mm}(5 \mu \mathrm{m})$ Zorbax SB-C ${ }_{18}$ column (Agilent Technologies Industries Co., Ltd., USA) using an Agilent G1311A pump and a UV Detector at $263 \mathrm{~nm}$. The mobile phase is a mixture of water and methanol at a flow rate of $1.0 \mathrm{~mL} / \mathrm{min}$. The volumetric ratio of water to methanol and the retention times for 6 -azauridine and its 5'-O-palmitate were $15 / 85,2.21$ and $15.98 \mathrm{~min}$, respectively.

Purification and structure determination of the esters: Upon the completion of the reaction, the immobilized enzyme was filtered off and the residue was then separated and purified through flash column chromatography using ethyl acetate/ petroleum ether as the mobile phase. The structure of the ester derivatives was determined by ${ }^{13} \mathrm{C}$ and ${ }^{1} \mathrm{H}$ NMR (Bruker DRX400 NMR spectrometer, Bruker Co., Germany) at 100 and $400 \mathrm{MHz}$, respectively. DMSO- $d_{6}$ was used as the solvent.

6-Azauridine ${ }^{1} \mathrm{H}$ NMR: $\delta 12.18\left(1 \mathrm{H}\right.$, br s, $\left.\mathrm{H}_{3}\right), 7.51(1 \mathrm{H}$, $\left.\mathrm{s}, \mathrm{H}_{5}\right), 5.84\left(1 \mathrm{H}, \mathrm{m}, \mathrm{H}_{1^{\prime}}\right), 5.20\left(1 \mathrm{H}\right.$, br s, $\left.\mathrm{OH}_{2}\right), 4.97(1 \mathrm{H}$, br s, $\left.\mathrm{OH}_{3^{\prime}}\right), 4.59\left(1 \mathrm{H}\right.$, br s, $\left.\mathrm{OH}_{5^{\prime}}\right), 4.18\left(1 \mathrm{H}, \mathrm{m}, \mathrm{H}_{2^{\prime}}\right), 3.96(1 \mathrm{H}, \mathrm{m}$, $\left.\mathrm{H}_{3^{\prime}}\right), 3.75\left(1 \mathrm{H}, \mathrm{m}, \mathrm{H}_{4^{\prime}}\right), 3.48-3.46\left(1 \mathrm{H}, \mathrm{m}, \mathrm{H}_{5^{\prime}-\mathrm{a}}\right), 3.36-3.32(1 \mathrm{H}$, m, $\left.\mathrm{H}_{5^{\prime}-\mathrm{b}}\right) .{ }^{13} \mathrm{C}$ NMR: $\delta 156.94\left(\mathrm{C}_{4}\right), 148.81\left(\mathrm{C}_{2}\right), 136.77\left(\mathrm{C}_{5}\right)$, $89.74\left(\mathrm{C}_{1^{\prime}}\right), 84.99\left(\mathrm{C}_{4^{\prime}}\right), 72.69\left(\mathrm{C}_{2^{\prime}}\right), 70.73\left(\mathrm{C}_{3^{\prime}}\right), 62.39\left(\mathrm{C}_{5^{\prime}}\right)$.
6-Azauridine palmitate ${ }^{1} \mathrm{H}$ NMR: $\delta 12.25\left(1 \mathrm{H}, \mathrm{br} \mathrm{s}, \mathrm{H}_{3}\right)$, $7.55\left(1 \mathrm{H}, \mathrm{s}, \mathrm{H}_{5}\right), 5.90\left(1 \mathrm{H}, \mathrm{d}, J=4 \mathrm{~Hz}, \mathrm{H}_{1^{\prime}}\right), 5.39(1 \mathrm{H}$, br s, $\left.\mathrm{OH}_{2^{\prime}}\right), 5.21\left(1 \mathrm{H}\right.$, br s, $\left.\mathrm{OH}_{3^{\prime}}\right), 4.27\left(1 \mathrm{H}, \mathrm{d}, J=8 \mathrm{~Hz}, \mathrm{H}_{2^{\prime}}\right), 4.19$ $\left(1 \mathrm{H}\right.$, br s, $\left.\mathrm{H}_{3^{\prime}}\right), 4.05\left(1 \mathrm{H}, \mathrm{s}, \mathrm{H}_{4^{\prime}}\right), 3.98-3.92\left(2 \mathrm{H}, \mathrm{m}, \mathrm{H}_{5^{\prime}}\right), 2.27$ $\left(2 \mathrm{H}, \mathrm{t}, J=8 \mathrm{~Hz}, \mathrm{H}_{2^{\prime \prime}}\right), 1.49$ (2H, br s, $\left.\mathrm{H}_{3^{\prime \prime}}\right), 1.23\left(24 \mathrm{H}, \mathrm{m}, \mathrm{H}_{4}{ }^{\prime \prime}+\right.$ $\mathrm{H}_{5^{\prime \prime}}+\mathrm{H}_{6^{\prime \prime}}+\mathrm{H}_{7^{\prime \prime}}+\mathrm{H}_{8^{\prime \prime}}+\mathrm{H}_{9^{\prime \prime}}+\mathrm{H}_{10^{\prime \prime}}+\mathrm{H}_{11^{\prime \prime}}+\mathrm{H}_{12^{\prime \prime}}+\mathrm{H}_{13^{\prime \prime}}+\mathrm{H}_{14^{\prime \prime}}+$ $\left.\mathrm{H}_{15^{\prime \prime}}\right), 0.85\left(3 \mathrm{H}, \mathrm{t}, J=8 \mathrm{~Hz}, \mathrm{H}_{16^{\prime \prime}}\right) .{ }^{13} \mathrm{C} \mathrm{NMR}: \delta 148.58\left(\mathrm{C}_{2}\right)$, $156.87\left(\mathrm{C}_{4}\right), 136.83\left(\mathrm{C}_{5}\right), 90.20\left(\mathrm{C}_{1^{\prime}}\right), 72.99\left(\mathrm{C}_{2^{\prime}}\right), 71.02\left(\mathrm{C}_{3^{\prime}}\right)$, $81.28\left(\mathrm{C}_{4^{\prime}}\right), 64.51\left(\mathrm{C}_{5^{\prime}}\right), 14.38\left(\mathrm{C}_{16^{\prime \prime}}\right), 22.57\left(\mathrm{C}_{15^{\prime \prime}}\right), 24.84\left(\mathrm{C}_{3^{\prime \prime}}\right)$, 28.92-29.53( $\mathrm{C}_{4^{\prime \prime}}+\mathrm{C}_{5^{\prime \prime}}+\mathrm{C}_{6^{\prime \prime}}+\mathrm{C}_{7^{\prime \prime}}+\mathrm{C}_{8^{\prime \prime}}+\mathrm{C}_{9^{\prime \prime}}+\mathrm{C}_{10^{\prime \prime}}+\mathrm{C}_{11^{\prime \prime}}+\mathrm{C}_{12^{\prime \prime}}$ $\left.+\mathrm{C}_{13^{\prime \prime}}+\mathrm{C}_{14^{\prime \prime}}\right), 31.78\left(\mathrm{C}_{2^{\prime \prime}}\right), 173.14\left(\mathrm{C}_{1^{\prime \prime}}\right)$.

\section{RESULTS AND DISCUSSION}

Effect of reaction medium: The specificity of TLL on the acylation of 6-azauridine was determined in several typical polar organic solvents, such as acetone, tetrahydrofuran, N,Ndimethylformamide and dimethyl sulfoxide. As showed in Table-1, DMF and DMSO had an inhibitory effect on activity of the enzyme. The dehydration of enzyme in hydrophilic organic solvents can cause minor structural perturbations resulting in inactivation ${ }^{17}$. Of the four tested pure organic solvents, acetone proved to be the most favourable one with respect to substrate conversion $(88.2 \%)$. However, it was noted that the initial reaction rate $(9.2 \mathrm{mM} / \mathrm{h})$ was very slow and a long time was required to reach reaction equilibrium even in acetone.

\begin{tabular}{|c|c|c|c|}
\hline \multicolumn{4}{|c|}{$\begin{array}{l}\text { TABLE-1 } \\
\text { ORGANIC SOLVENTS ON } \\
\text { 2EGIOSELECTIVE ACYLATION } \\
\text { E WITH VINYL PALMITATE }^{\mathrm{a}}\end{array}$} \\
\hline Solvent (s) & $\begin{array}{c}\mathrm{V}_{0} \\
(\mathrm{mM} / \mathrm{h})\end{array}$ & $\begin{array}{c}C^{b} \\
(\%)\end{array}$ & $\begin{array}{c}\text { 5'-Regio- } \\
\text { selectivity }(\%)\end{array}$ \\
\hline DMF & n.d. ${ }^{\mathrm{c}}$ & n.d. & n.d. \\
\hline DMSO & n.d. & n.d. & n.d. \\
\hline Acetone & 9.2 & 88.2 & 99 \\
\hline Acetone/DMF (3:1) & 3.2 & 42.0 & 99 \\
\hline Acetone/DMSO (3:1) & n.d. & n.d. & n.d. \\
\hline Acetone/t-Butanol (3:1) & 7.4 & 90.1 & 99 \\
\hline Acetone/isooctane (3:1) & 14.6 & 95.7 & 99 \\
\hline Acetone/isopropyl ether $(3: 1)$ & 13.7 & 94.0 & 99 \\
\hline Acetone/hexane (3:1) & 12.5 & 92.9 & 99 \\
\hline Acetone/cyclohexane $(3: 1)$ & 10.6 & 92.2 & 99 \\
\hline $\mathrm{THF}$ & 4.7 & 77.5 & 99 \\
\hline THF/DMSO (3:1) & n.d. & n.d. & n.d. \\
\hline THF /isopropyl ether (3:1) & 4.9 & 66.6 & 99 \\
\hline THF /hexane $(3: 1)$ & 5.0 & 77.9 & 99 \\
\hline \multicolumn{4}{|c|}{$\begin{array}{l}{ }^{a} \text { The reactions were carried out at } 35^{\circ} \mathrm{C}, 200 \mathrm{rpm} \text { by adding } 10 \mathrm{mM} \\
6 \text {-azauridine, } 50 \mathrm{mM} \text { vinyl palmitate, } 750 \mathrm{U} \text { TLL into } 2 \mathrm{~mL} \text { anhydrous } \\
\text { pure solvent or co-solvent mixture. }{ }^{\mathrm{b}} \text { Maximum conversion of substrate. } \\
{ }^{\mathrm{c}} \text { Not deteted. }\end{array}$} \\
\hline
\end{tabular}

As an alternative, it is well-documented that the use of cosolvents can not only efficiently improve the catalytic activity but also adjust selectivity of the enzyme ${ }^{18,19}$. Therefore, the effect of organic co-solvents to change the property of the enzyme was subsequently examined. As a consequence, the addition of isooctane, isopropyl ether, hexane and cyclohexane to acetone resulted in a clear enhanced reaction rate (14.6, $13.7,12.5$ and $10.6 \mathrm{mM} / \mathrm{h}$, respectively). Among the solvents assayed, acetone/isooctane (3:1 v/v) gave the highest initial reaction rate and substrate conversion. A speculative explanation 
could be that the lowering of the polarity of the reaction system caused by addition of the hydrophobic organic solvents allowed adequate water molecular to bind close to the active site and maintain the suitable catalytic conformation of the enzyme, thus stabilizing the enzyme-substrate intermediate and accelerating the enzymatic reaction ${ }^{20}$. Besides, 6-azauridine showed relatively lower ground state energy in a more hydrophobic co-solvent mixture and was more easily accessible to the active site of the enzyme, thereby resulting in a higher substrate concentration around the enzyme active site and a high initial rate of the reaction ${ }^{21}$.

However, both low reaction rate and conversion were observed in THF/isopropyl ether $(3: 1 \mathrm{v} / \mathrm{v})$ and THF/hexane $(3: 1 \mathrm{v} / \mathrm{v})$. The less flexible structure of the enzyme in more hydrophobic media may account for this. It was also notable that the reaction medium showed little effect on the regioselectivity.

Effect of isooctane content in co-solvent mixture: As can be seen in Table-2, the initial reaction rate soared rapidly with the increase of isooctane content up to $10 \%(\mathrm{v} / \mathrm{v})$ in the co-solvent mixture owing to less inactivation effect of a hydrophobic solvent on the enzyme. However, a further rise in content of isooctane beyond $10 \%(\mathrm{v} / \mathrm{v})$ led to a drop in the initial reaction rate and conversion, suggesting the lower solubility of the substrate in the hydrophobic reaction mixture and the too flexible active site of the enzyme. So, the optimal content of isooctane in the co-solvent mixture was thought to be $10 \%(\mathrm{v} / \mathrm{v})$.

TABLE-2

EFFECT OF ISOOCTANE CONTENT ON

TLL-CATALYZED REGIOSELECTIVE ACYLATION OF 6-AZAURIDINE WITH VINYL PALMITATE

\begin{tabular}{lccc}
\hline \multicolumn{1}{c}{ Co-solvent mixture } & $\mathrm{V}_{0}(\mathrm{mM} / \mathrm{h})$ & $\begin{array}{c}\mathrm{C} \\
(\%)\end{array}$ & $\begin{array}{c}\text { 5'-Regio- } \\
\text { selectivity (\%) }\end{array}$ \\
\hline Acetone/isooctane (95:5) & 14.3 & 99.0 & 99 \\
Acetone/isooctane (90:10) & 17.0 & 99.3 & 99 \\
Acetone/isooctane (85:15) & 16.4 & 98.3 & 99 \\
Acetone/isooctane (75:25) & 14.6 & 95.7 & 99 \\
Acetone/isooctane (65:35) & 11.8 & 92.5 & 99 \\
\hline
\end{tabular}

${ }^{a}$ The reactions were carried out at $35^{\circ} \mathrm{C}, 200 \mathrm{rpm}$ by adding $10 \mathrm{mM}$ 6-azauridine, $50 \mathrm{mM}$ vinyl palmitate, $750 \mathrm{U}$ TLL into $2 \mathrm{~mL}$ anhydrous co-solvent mixture.

Effect of molar ratio of vinyl palmitate to 6-azauridine: There is a competitive hydrolysis of acyl donors in which water works as a nucleophilic agent ${ }^{22}$. Accordingly, an excessive amount of acyl donors is normally necessary. As depicted in Fig. 1, the enzymatic acylation of 6-azauridine was greatly affected by the molar ratio of vinyl palmitate to 6-azauridine. Remarkable improvement in both the initial rate and substrate conversion was observed with the increase of the ratio up to 5 , which was the optimal ratio of vinyl palmitate to 6-azauridine.

Effect of reaction temperature: The temperature has a significant influence on the property of a lipase and the reaction equilibrium. As show in Fig. 2, a higher temperature resulted in a higher initial reaction rate within the range from $35-50^{\circ} \mathrm{C}$ and further rise in temperature (above $50^{\circ} \mathrm{C}$ ) brought a decline in initial rate, due to the partial inactivation of the lipase in acetone/isooctane co-solvent $(90: 10 \mathrm{v} / \mathrm{v})$ at higher temperatures. Within the assayed range, the reaction temperature showed no significant effect on the regioselectivity.

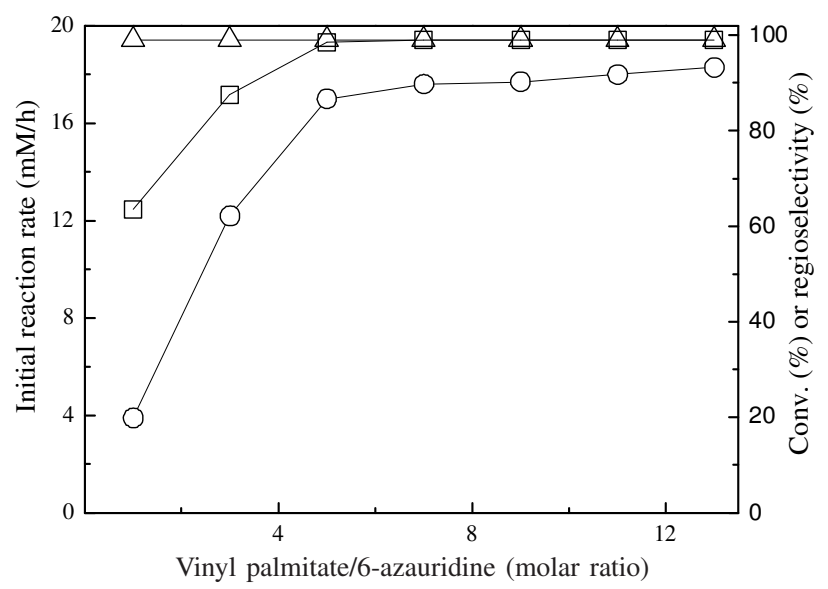

$\multimap-$ : Initial reaction rate; $\square-$ : Maximum conv.; $\triangle$ : Regioselectivity

Fig. 1. Effect of the molar ratio of vinyl palmitate to 6-azauridine on TLLcatalyzed acylation of 6-azauridine. The reactions were carried out at $35^{\circ} \mathrm{C}, 200 \mathrm{rpm}$ by adding $10 \mathrm{mM}$ 6-azauridine, $750 \mathrm{U}$ TLL, various volume vinyl palmitate into $2 \mathrm{~mL}$ anhydrous acetone/isooctane $(90: 10 \mathrm{v} / \mathrm{v})$

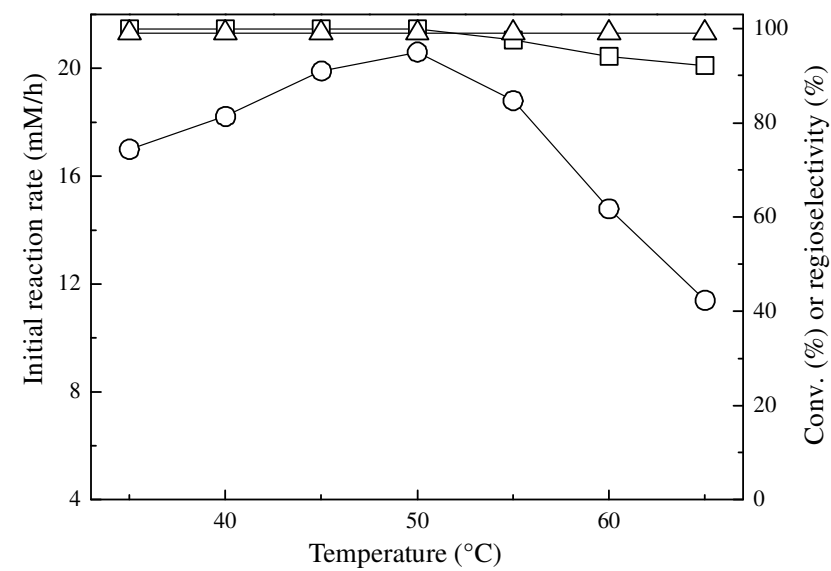

- - Initial reaction rate; $\square-\square$ : Maximum conv.; $\triangle$ : Regioselectivity

Fig. 2. Effect of the temperature on TLL-catalyzed acylation of 6-azauridine with vinyl palmitate. The reactions were carried out at $200 \mathrm{rpm}$, various temperatures from $35-65^{\circ} \mathrm{C}$ by adding $750 \mathrm{U}$ TLL, $10 \mathrm{mM}$ 6-azauridine, $50 \mathrm{mM}$ vinyl palmitate into $2 \mathrm{~mL}$ anhydrous acetone/ isooctane $(90: 10 \mathrm{v} / \mathrm{v})$

Thermal and operational stability of the enzyme: Comparison between the residual enzymatic activities obtained after preincubation for $6.5 \mathrm{~h}$ at various temperatures in the co-solvent mixture and pure solvent was shown in Fig. 3. In anhydrous acetone/isooctane (90:10 v/v), the enzyme maintained $58 \%$ of its initial activity against $40 \%$ in anhydrous acetone. The results suggested that the addition of the strongly hydrophobic solvent to the polar reaction medium could efficiently protect the essential water surrounding the lipase and change ionic interactions within the three dimensional structure of the protein, thus altering the rigidity of the enzyme thereby particularly improving the thermal stability of TLL markedly. Control experiments were also conducted to observe the operational stability of the enzyme in both solvent systems. As evident from the data depicted in Fig. 4, the lipase still retained more than $70 \%$ of its original activity even after being repeatedly employed for five batches ( $6.5 \mathrm{~h}$ reaction time for each batch) in anhydrous acetone/isooctane co-solvent (90:10 v/v) while only $37 \%$ activity was recovered under the same conditions 


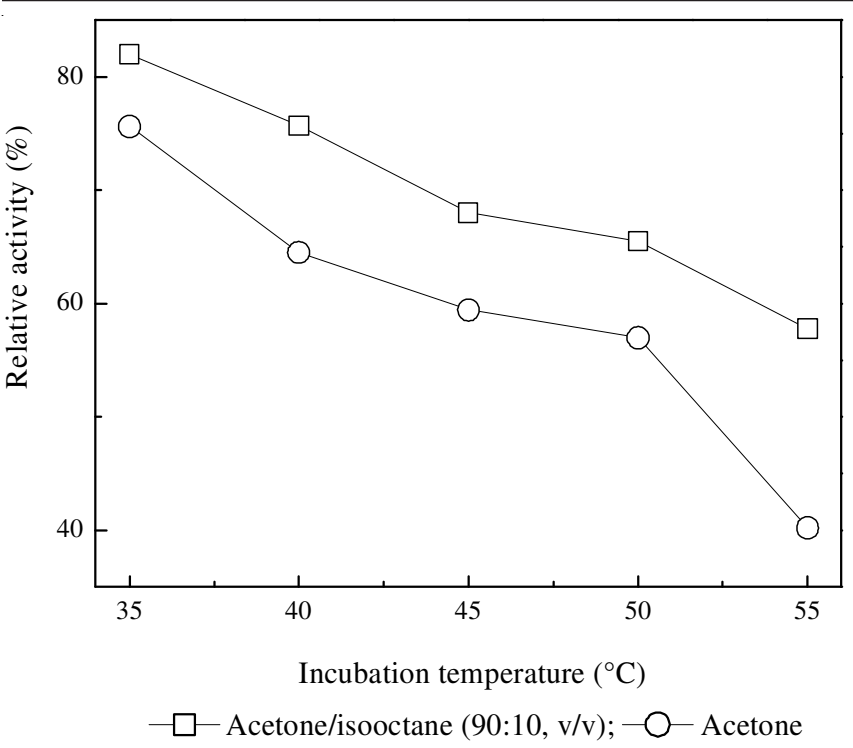

Fig. 3. Thermal stability of liopozyme TL IM. The reactions were carried out at $50{ }^{\circ} \mathrm{C}, 200 \mathrm{rpm}$ by adding $750 \mathrm{U}$ TLL, $10 \mathrm{mM}$ 6-azauridine and $50 \mathrm{mM}$ vinyl palmitate into $2 \mathrm{~mL}$ anhydrous acetone/isooctane $(90: 10 \mathrm{v} / \mathrm{v})$

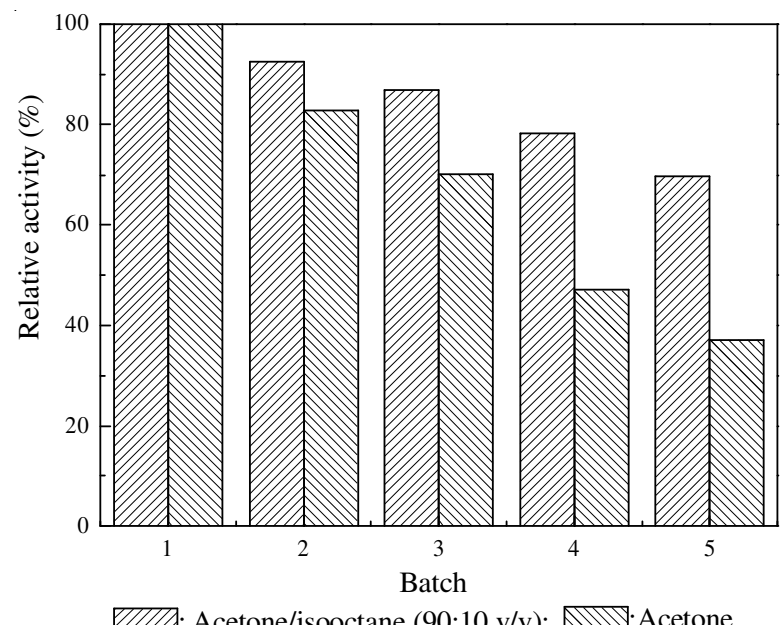

Fig. 4. Operational stability of TLL. The reactions were carried out at $50{ }^{\circ} \mathrm{C}$, $200 \mathrm{rpm}$ by adding $750 \mathrm{U}$ TLL, $10 \mathrm{mM} 6$-azauridine and $50 \mathrm{mM}$ vinyl palmitate into $2 \mathrm{~mL}$ anhydrous acetone/isooctane $(90: 10 \mathrm{v} / \mathrm{v})$

in anhydrous acetone. It can be concluded that TLL showed good thermal and operational stability in the co-solvent system in contrast to pure solvent system.

\section{Conclusion}

The excellent thermal stability and the possibility of recycling are decisive parameters for the catalysis from both a practical and a theoretical viewpoint. The results obtained in this paper clearly demonstrate that co-solvents can serve as an excellent reaction system in place of traditional pure organic solvent for TLL-mediated acylation of 6-azauridine with greatly improved enzyme stability. Therefore, this methodology of enzymatic-solvent engineering is of significance in synthetic applications. Furthermore, the more advantageous co-solvent system is currently being developed and will be reported in due course to further improve enzyme properties.

\section{ACKNOWLEDGEMENTS}

This research was sponsored by Qing Lan Project of Jiangsu Province, Natural Science Foundation of Jiangsu Province (No. BK2012243), Foundation of Jiangsu Provincial Engineering Laboratory for Advanced Materials of Salt Chemical Industry (SF201310), Foundation of Jiangsu Provincial Engineering Laboratory for Biomass Conversion and Process Integration (JPELBCPL2013005) and Natural Science Research Project of Higher Education of Jiangsu Province (No. 10KJB530001).

\section{REFERENCES}

1. A.P. Borole, C.L. Cheng and B.H. Davison, Biotechnol. Prog., 20, 1251 (2004).

2. S. Cantone, U. Hanefeld and A. Basso, Green Chem., 9, 954 (2007).

3. J.M. Crance, N. Scaramozzino, A. Jouan and D. Garin, Antiviral Res., 58, 73 (2003).

4. H. Fan, M. Kitagawa, T. Raku and Y. Tokiwa, Biotechnol. Lett., 26, 1261 (2004).

5. M. Ferrero and V. Gotor, Chem. Rev., 100, 4319 (2000).

6. M. Ferrero and V. Gotor, Monatsh. Chem., 131, 585 (2000).

7. A.M. Gumel, M.S.M. Annuar, T. Heidelberg and Y. Chisti, Process Biochem., 46, 2079 (2011).

8. M.Y. Lee and J.S. Dordick, Curr. Opin. Biotechnol., 13, 376 (2002).

9. N. Li, T.J. Smith and M.H. Zong, Biotech. Adv., 28, 348 (2010).

10. X.F. Li, M.H. Zong and G.L. Zhao, Appl. Microbiol. Biotechnol., 88, 1 (2010).

11. A. Matsuda and T. Sasaki, Cancer Sci., 95, 105 (2004).

12. J. Paragas, C.A. Whitehouse, T.P. Endy and M. Bray, Antiviral Res., 62, 21 (2004)

13. Z.Y. Wang, N. Li and M.H. Zong, J. Mol. Catal. B: Enzymatic, 59, 212 (2009).

14. Z.Y. Wang and M.H. Zong, Biotechnol. Prog., 25, 784 (2009).

15. Z.Y. Wang and M.H. Zong, Chin. J. Catal., 32, 357 (2011).

16. Z.Y. Wang and M.H. Zong, Chin. J. Org. Chem., 31, 1032 (2011).

17. H.K. Weber, H. Weber and R.J. Kazlauskas, Tetrahedron: Asymm., 10, 2635 (1999).

18. J. Wu, M.H. Zong, H. Wu and W.Y. Lou, J. Chem. Technol. Biotechnol., 83, 814 (2008).

19. A. Zaks and A.M. Klibanov, J. Biol. Chem., 263, 8017 (1988).

20. H. Zhao, L. Jackson, Z. Song and O. Olubajo, Tetrahedron: Asymm., 17, 2491 (2006).

21. H. Zhao, Y. Zhang, F. Lu, X. Bie, Z. Lu and H. Ning, J. Mol. Catal. B: Enzymatic, 69, 107 (2011).

22. J. Zhou, C.M. Riley and R.L. Schowen, J. Pharm. Biomed. Anal., 26, 701 (2001). 